\title{
marketing.
}

ČLANCI/PAPERS

\section{How to Write Cases and Teaching Notes in Marketing Education?}

\author{
Vesna Damnjanović, Slavica Cicvarić Kostić, \\ Ema Nešković
}

\begin{abstract}
This paper presents guidelines for developing cases and teaching notes for marketing classes in higher education. Cases are often used in problem-based learning, where students are placed in a problem or decision-making situation and are encouraged to take the role of problem solvers. The recommendations for case writing are based on analysis of high-level examples of marketing cases, published in the most prominent global publishing databases, along with more than 15 years of experience of the authors. This paper explains the process of writing cases depending on the source of data and tackles all necessary issues that should be addressed. Writing teaching notes is focused on providing the supportive material for a case that helps a lecturer understand the reason for writing the case, the questions that might arise from it and the professional or theoretical points that should be raised in discussion. This paper should contribute to interactive learning and provide lecturers with detailed recommendations for writing cases in the marketing field.
\end{abstract}

Key words: writing cases, teaching notes, marketing, higher education
JEL: M31, I23

\section{INTRODUCTION}

The main role of educational institutions for business studies is to help students develop managerial skills and prepare them for their future careers (Burke et al, 2013). Teaching at higher educational institutions in Eastern European countries, was and still is predominantly based on traditional ex-cathedra lecturing and transmission-based teaching, rather than constructivist approaches that allow the development of critical thinking skills (Mijatovic \& Jednak, 2011). A research study from Singapore points out that lecturers and educational institutions need to be responsive to changes and improvements in interactive learning, and one of the ways to do this is to use the case method in the classroom (Chong, 2012). Furthermore, the International Association for Management Education has created mission-driven accreditation standards that are nearly impossible to meet without the use of case pedagogy in higher education (Crespy et al., 1999). Additionally, many changes have occurred in the context of marketing education, including the use of new technology-based (Hall and Witek, 2016) and experiential learning (Kolb and Kolb, 2005). Rather than having lecturers telling students what they know, they need to ask questions that lead students along the path of learning. Lecturers also need to become better storytellers, speak more vividly, communicate more visually, and work hard to keep students engaged and involved.

The case method will become an even more important means for interactive learning. While the case method is evolving, it has a rich history in marketing education. Just knowing about marketing has not been viewed as adequate preparation for a career in marketing. Students must have the opportunity to practice problem solving and decision-making in a marketing context. This is precisely what the case method is all about (Hawes, 2004). The case method is not only the most relevant and practical way to learn managerial skills, but it is exciting and beneficial for students (Karns, 2005). It calls for discussion of real-life situations that business executives have faced. Furthermore, it helps sharpen analytical skills, develop problem-solving approaches and the ability to think and reason rigorously (Hammond, 1976). 
Although marketing lecturers recognize the need and benefits of utilizing the case method in their lectures (Yadav, 2007), the experience of the authors shows that lecturers often do not know how to prepare the case and teaching notes for the class. Generally, there is some misunderstanding in academia about the difference between teaching cases and research cases. According to Farhoomand (2004) writing a teaching case is more comparable to writing a spy thriller than a research article. The purpose of this paper is to present guidelines for preparing materials for class, including cases and teaching notes. The guidelines are developed on the basis of secondary data, available literature and instructions provided by reputable case study databases, but also the experience of the authors who have used the case method in lecturing for over 15 years.

Salles et al. (2015) identified that teaching cases are sorted into three different categories according to the way they are used in the classroom. The first category is case-statement, which is used to illustrate lectures to demonstrate good marketing management practices that have been applied in a given situation. The second and most complex category is case-problem. Students are urged to identify management problems, discuss possible solutions and weigh the advantages and disadvantages of each. The third category is caseanalysis, where students are asked to analyze cases and their variables in order to relate them to the problems. Haskins (1992) identified two types of teaching cases: the purely descriptive and the decision-oriented. A descriptive case generally describes a situation, the related facts and the decision, and is often used to exemplify the good or poor implementation of a technique or framework. On the other hand, the decision-oriented case is problem based, including problem identification, analysis and action planning, providing a strong basis for discussion and learning. In this paper we will focus on problem-based learning or decision oriented cases, as the authors have found them most useful for developing managerial skills of students.

The paper is structured as follows: the next section outlines the main steps in the case writing process. The third section examines the main elements of a marketing case, followed by the fourth section, which explores how to develop teaching notes for the case. In the fifth section, the authors give advice for publishing cases and teaching notes in marketing. The last section presents conclusions and identifies future directions for research in this field.

\section{IDENTIFYING THE SOURCES OF DATA FOR CASE WRITING}

The first step in writing cases is deciding the data source for the case. Cases can be written using one of the following sources of data: primary source with the approval given by the company that the case study is being written about, secondary source and professional experience of the author/s. (Damnjanovic, 2011). In this paper, guidelines for all three ways of writing cases and teaching notes for marketing lecturers will be outlined.

\subsection{Primary source of data for case writing}

In using a primary data source, authors have to choose a company that will provide the data for the case. David (2003) gave some advice on how to select a case company. He suggested that it could be an existing organization undergoing strategic change or doing business globally, an organization that is in the news, as well as an organization operating in industries familiar to the students. One of the most productive sources of case leads are former students from an alumni network (Haskins, 1992). The alumni network can bridge companies willing to cooperate and universities.

After choosing a company, case writers should contact the company's Marketing Department representative. Case writers usually receive necessary data from various management levels including: Marketing Director, Brand Director, Product Director, Shopper Marketing Director, Sales Director, Digital Marketing Director or Chief Marketing Officer.

Firstly, case writers prepare the draft version of the teaching case with primary data from the company as well as all available data form secondary sources. Next, case writers should discuss the draft version with a company representative and agree about potential changes and revision. It is important to emphasize that writers can modify some data to protect confidential business information.

Prior to publishing the case, it must be approved by the CEO of the case company. The confirmation is usually given via the Case Release form, presented in Figure 1 (Leendres et al., 2001). According to The World Association for Case Method Research \& Application, formal release of the case protects both sides from misuse of data (Swiercz, 2016).

Using primary sources of data for case writing has its advantages and disadvantages. The greatest value is the direct contact with the company. Company rep- 


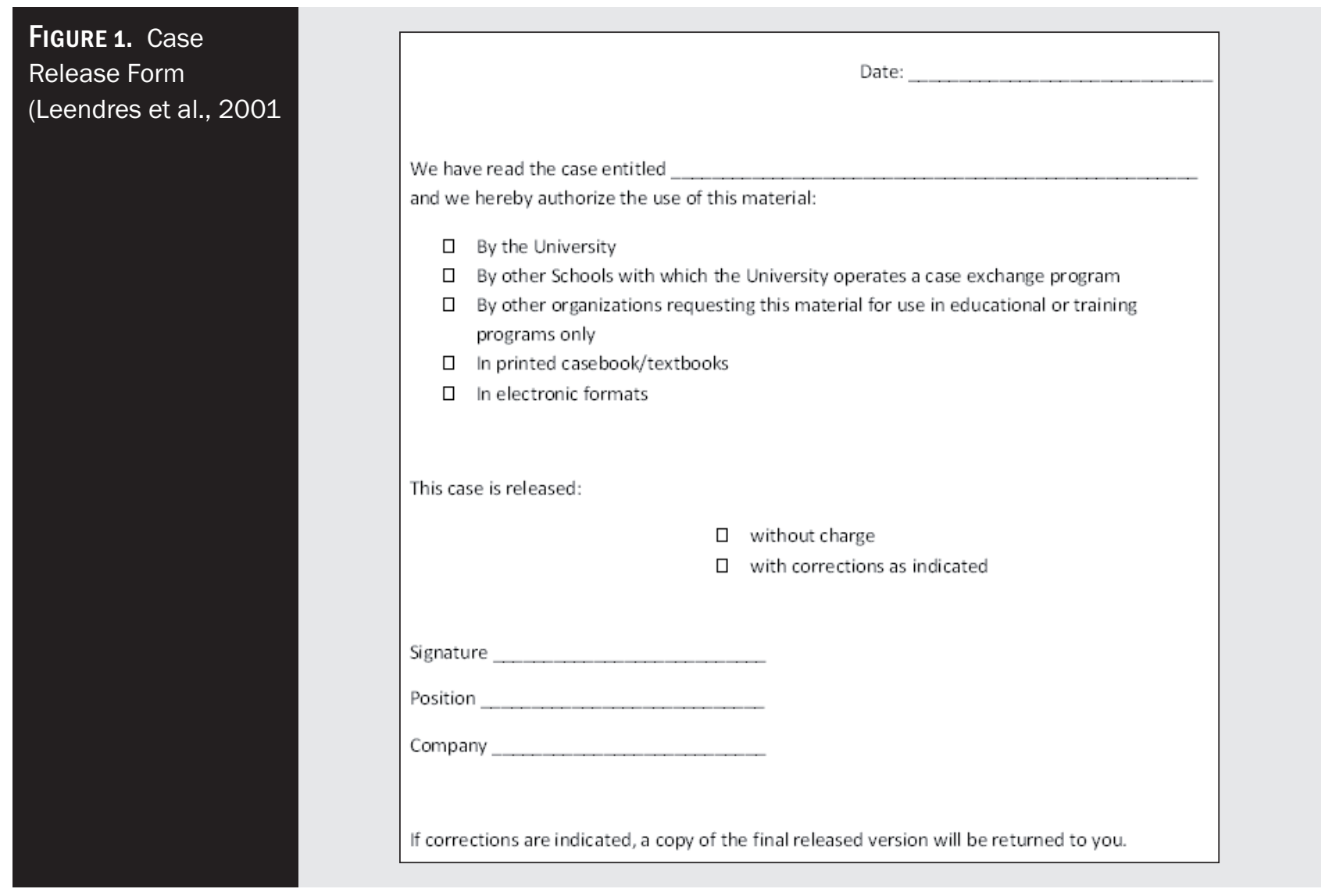

resentatives can be asked to introduce the case in the classroom and give valuable insights from the industry, market or everyday business. Ultimately, students receive information through this medium that would be difficult to retrieve from other data sources. The greatest downside to using primary data is the substantial amount of time necessary to properly structure the case and complete the company consultation and consent process.

\subsection{Secondary source of data for case writing}

The second option for writing cases is to use secondary data that can be retrieved from already published sources. It can be obtained from a myriad of documents, such as annual reports, industry surveys, professional association reports, company websites, Internet, television and radio reports, books, magazines, trade publications and others. A strong recommendation from the Case Centre is to acknowledge the cop-

\section{TABLE 1.}

\begin{tabular}{l|l}
\hline Case database & Web page \\
\hline The Case Centre (ECCH) & https://www.thecasecentre.org/main/ \\
\hline Harvard Business Publishing & https://cb.hbsp.harvard.edu/cbmp/pages/home \\
\hline Ivey Publishing & https://www.iveycases.com/PublishCases.aspx \\
\hline Asian Business Case Centre & http://www.asiacase.com/ \\
\hline INSEAD & https://cases.insead.edu/publishing/ \\
\hline IBS Center for Management Research & http://www.icmrindia.org/ \\
\hline Asia Case Research Centre & http://www.acrc.hku.hk/casecompetition16/index.asp \\
\hline Emerald Emerging Markets Case Studies (EEMCS) & http://emeraldgrouppublishing.com/products/case_studies/index.htm \\
\hline Times Case Study & http://businesscasestudies.co.uk/ \\
\hline
\end{tabular}

SECONDARY SOURCE: Recommended case databases for locating cases in Marketing 
yright of the material prior to using it. Furthermore, data used from secondary sources must be referenced in a list at the end of the case. In particular, the link and the date of downloading have to be stated for Internet sources.

As secondary sources are generally publically available, there is no need to get the permission from the company for publishing the case. Another advantage of using secondary data is that the authors can update the case with the latest information in a timely manner. The main obstacle of using secondary sources is the fact that sometimes it is hard to find relevant data that authors need to write a good case.

The main source for cases based on secondary data is case databases. Table 1 presents a list of the most relevant and popular case databases worldwide.

\subsection{Professional experience of the authors as a source for case writing}

Finally, cases can be successfully written on the basis of the author's professional experience. Usually, the authors write a case based on a situation in which they were involved. In this situation, company names are altered. An example of such a case can be found in AT Kearney (2012).

\section{THE STRUCTURE OF A CASE IN MARKETING}

A case may consist of one or more scenarios, and it may take many forms, from a traditional paper-based document to videos or audio recordings. There is no limit for the amount of content in a case, but David (2003) recommends 10 to 15 pages as an optimum for strategic marketing cases. The structure of a case is usually presented as a funnel, with information narrowing down from general data to specific requirements of the case (Figure 2). Standard elements of a case in marketing are an opening section, main body and conclusion.

The opening section usually consists of one to three paragraphs, serving as the stage setting and a "hook" at the same time. In this section various contextual questions are answered including when, where, who, what, why and how. Case writers should present the protagonist (name and position of the decision maker), what kind of a decision he/she has to make, when and where this is happening, and why and how this would happen (RSM Case Development Centre, 2016). Having a decision-maker persona for the students to adopt is not an absolute requirement but often highly recommended (Sjoblom, 2014). Data that is already available and additional data that needs to be gathered should be included in the opening paragraph as well.

To better understand how to write the introductory section, we present the example below (Damnjanovic, 2011b): "One chilly evening on the $29^{\text {th }}$ of September 2008, Mr Lazar Stojkovic, founder and CEO of touche' Solutions, a high-tech enterprise based in Serbia, was returning home from work when he observed a group of young people in the street gathered around a shopping window decorated with interesting fluorescent colors. They were amazed by the design and commented enthusiastically. Lazar was analyzing the market research information he had collected regarding the launch of his new product, an interactive shop window display, product name "streetone", that had been targeted for release in November 2008. He came to the conclusion that shop windows in the center of Belgrade, would present the most attractive location for positioning the new product and potentially yielding the highest financial rewards for the business. He was thinking about the optimum way to deliver the company's sales plan with a relatively limited budget. Funding had been significantly depleted after heavy investment in the research and development of the streetone product range. The key now was to prepare a strong sales presentation for his upcoming meeting with potential sales partner Mr Zvonko Radovanovic' on 20 October, the chief manager of the client-relations section of Energoprojekt-Energodata Company in Belgrade. He also had in mind three primary client segments: Banks, hospitality and tourism agencies. These had to be assessed and agreed within a four week deadline, and would inform the strategic direction the business would take in capturing these segments".

The main body of the case follows the opening section. It usually includes general company background, specific area the case covers, specific problem or decision that needs to be addressed and alternatives as possible solutions. According to Balakrishnan (2010) sub-headings should be used as they allow students to follow the story and easily find information. In order to present the structure of a case, two examples are summarized in Table 2.

The experience of the authors has shown that it is important to identify available data and note for each part of the case where research for additional data is required (Figure 2). 
TABLE 2. Examples of Case structure of main body of the case (Damnjanovic, 2011a)

\begin{tabular}{|l|l|l|}
\hline \multicolumn{1}{|c|}{ Case outline of main body by subtitles } & $\begin{array}{c}\text { Example of subtitle for } \\
\text { AMC Case }\end{array}$ & $\begin{array}{c}\text { Example of subtitle for The } \\
\text { Hyundai brand }\end{array}$ \\
\hline $\begin{array}{l}\text { Company Background } \\
\text { Description of specific area of the case }\end{array}$ & $\begin{array}{l}\text { The AMC Company } \\
\text { Portfolio Editions } \\
\text { Description Of The Women's } \\
\text { Magazine Segment }\end{array}$ & $\begin{array}{l}\text { About The Hyundai Company } \\
\text { The Automobile market In Serbia }\end{array}$ \\
\hline Fpecific problem or decision & Launch of Magazine Sensa & $\begin{array}{l}\text { Hyundai Cafe - A New Meeting } \\
\text { Place For Hyundai Car Lovers }\end{array}$ \\
\hline Final closing & Conclusion & Conclusion \\
\hline Additional material, statistics, charts, tables) & Figure 1,2,3 and Table 1. & Figure 1,2,3 and Table 1. \\
\hline
\end{tabular}

The final part of a case is a conclusion that should summarize the basic data and pinpoint the tasks for students. The following example illustrates how to formulate a conclusion (Damnjanovic, 2011c): "The marketing manager of Sensa magazine hired you as a consultant of the company Adria Media Serbia Ltd. to think about future promotional activities for the period between June of 2008 and June of 2009. The ATL activities (advertising, media appearances) have already been implemented, so the company plans to use that period to focus on BTL activities - sales promotions, organization of special events and promotions at the point of sale, direct communication with customers - with respect to the target groups' demands. The total costs of promotional BTL activities amount to 80,000 euro. The marketing department is also in a dilemma on how to devise the introduction of ad- ditional product lines for the Sensa brand, and thus obtain a better market position."

Cases are usually published in one of the databases previously listed in Table 1. More than 35.000 users are registered in the Case Centre at the global level. This network provides the opportunity to share cases with colleagues, improve collaboration with universities and companies and prepare students for their future career in marketing or more generally. For the purpose of publishing, a case should be tested in the classroom. This should be clearly noted in the case. This comprises statements of the context in which the material was taught, name of the institution at which it was taught, name of the lecturer who taught it, date when it was taught and the number of students in the classroom (The Case Centre, 2016). An important note is that the case will be used for educational pur-

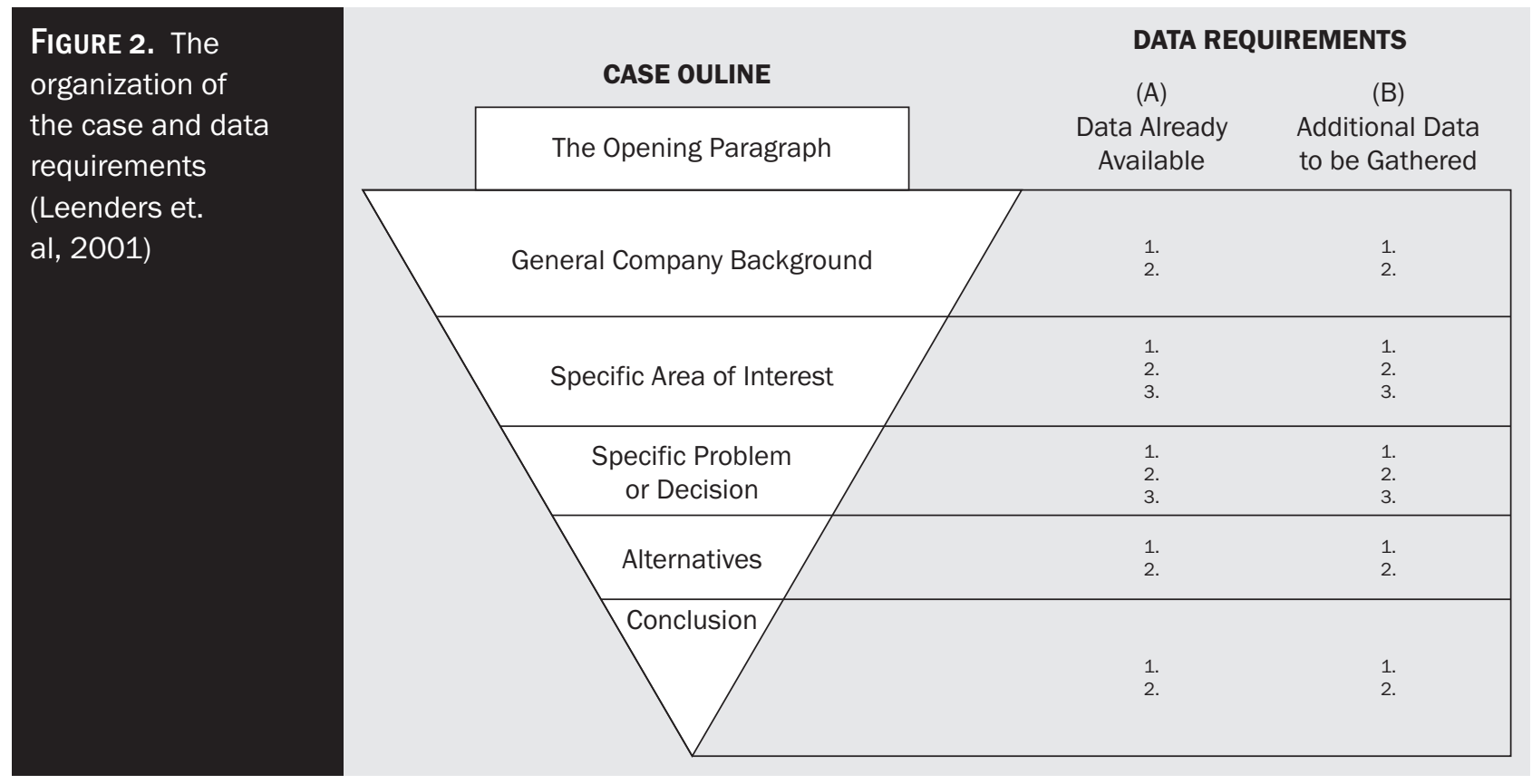




\section{marketing}

poses. After the submission of the case, the first page should include the logo of the educational institution, and accompanying text. An example is provided below:

"This case was written by Vesna Damnjanovic (University of Belgrade, Faculty of Organizational Sciences). It is intended to be used as the basis for class discussion rather than to illustrate either effective or ineffective handling of a management situation. The case was compiled from field research.(C) 2017, University of Belgrade, Faculty of Organizational Sciences.

No part of this publication may be copied, stored, transmitted, reproduced or distributed in any form or medium whatsoever without the permission of the copyright owner." (Damnjanovic, 2011c).

\section{DEVELOPING TEACHING NOTES FOR THE CASE}

A case is often accompanied by a set of teaching notes, one to several pages long. The teaching notes provide instructions for subsequent users of the case, whether it is the author or another individual. The notes are intended to help the lecturer understand the reason for writing the case, the questions that might arise from it and the professional or theoretical points that might be raised in discussion (Millar, 1999). Teaching notes can help lecturers facilitate the presentation of the case in class. The structure of teaching notes depends on the author and the type of case, but usually it includes the following parts (The Case Centre, Ivey Publishing):

TABLE 3. Example of teaching notes for the case Adria Media Serbia (Damnjanovic $2011 \mathrm{c}$, modified by the authors)

\begin{tabular}{|c|c|}
\hline Course & Marketing, Marketing Research, Brand Management \\
\hline Target audience & Undergraduate, MBA/post-graduate \\
\hline Topics & $\begin{array}{l}\text { Marketing research, Market segmentation, Positioning of the new brand, Brand } \\
\text { extension strategies }\end{array}$ \\
\hline Teaching objectives & $\begin{array}{l}\text { Understanding the role of the marketing research process in the process of launching } \\
\text { a new product brand into the Serbian market } \\
\text { Identifying the specifics of brand positioning of the Sensa magazine brand }\end{array}$ \\
\hline Relevant Readings & $\begin{array}{l}\text { More about Sensa brand: http://www.lovesensa.rs/ } \\
\text { Balkes, (1998), Magazines As Brands } \\
\text { More about brand in publishing: Branding Solutions For Tomorrow's Publisher, } \\
\text { Wessenden Marketing and First Magazine Marketing, http://www.brandlabuk.com/ } \\
\text { Branding\%20for\%20Tomorrow's\%20Publisher.pdf } \\
\text { The future of research New Censydiam: Ipsos Asia Pacific (2016), http:// } \\
\text { ipsosasiapacific.com/wp-content/uploads/sites/3/2016/07/03-New-Censydiam.pdf } \\
\text { More about Brand extension: Damnjanovic V. (2011), Hyundai brand, CASE - Reference } \\
\text { no. 510-038-1, The Case Centre }\end{array}$ \\
\hline Assignments & $\begin{array}{l}\text { Educator case introduction } \\
\text { - Explain the difference between qualitative and quantitative marketing research (10 } \\
\text { minutes) } \\
\text { - Present students with the characteristics of the publishing industry in Serbia (5 } \\
\text { minutes) } \\
\text { Student assignments: } \\
\text { 1.Discussing and understanding the meaning of the Censydiam approach? ( } 20 \\
\text { minutes) Damnjanovic ( } 2017 \text { ) } \\
\text { 2.Analyze the target groups for Sensa magazine (10 minutes) } \\
\text { 3.Define a BTL promotional activity plan for Sensa magazine ( } 20 \text { minutes) } \\
\text { 4.Propose brand extension strategies for Sensa magazine (15 minutes) } \\
\text { 5.Summary of the discussion (10 minutes) }\end{array}$ \\
\hline $\begin{array}{l}\text { Learning outcomes: } \\
\text { Key knowledge and skills }\end{array}$ & $\begin{array}{l}\text { - Using marketing research information for making business decision } \\
\text { - Understanding brand positioning and premium magazine segment } \\
\text { - Development of a new magazine brand through a promotional below the line (BTL) } \\
\text { activity plan } \\
\text { - Market segmentation skills based on social and individual (personal) dimensions }\end{array}$ \\
\hline
\end{tabular}


- Case study title, where the case study name is emphasized.

- Description of the case study, a short description of the particular case.

- Learning objectives, the part that defines the study goals to be accomplished in a class. There is also the option of defining priorities within the study goals - primary as the main goal and secondary as side goals.

- Course that a case is suitable for, as well as the level of studies for which a case is appropriate.

- Relevant readings that are recommended as an additional material for deeper understanding of the case. These readings could be given in the form of a framework, theory, etc.

- Assignment questions, which match the headers of the Analysis section.

- Main problems of the case, which provide rationale for the lecturer applying the case in the learning process.

- Additional materials for the case, such as TV commercials, photos, articles and videos. A recommended reading list is also a good addition. It is important to offer additional sources, such as books, articles, and websites, for the students that are particularly interested in the subject.

- Real scenario of the case, which provides a brief summary of the actual outcome of the situation. Here, the focus should be on the decisions that were actually made and their results.

Generally, case authors need to define the target group of students and types of marketing courses where a case can be used and decide whether it is more suitable for the undergraduate, graduate or executive program. Sometimes case writers define that one case can be used for different levels of studies, but they should specify different teaching strategies to be used Furthermore, it is useful to connect the case with theoretical methods (eg. SWOT analysis), techniques (eg. Censydiam segmentation approach) and models (eg. sales funnel) used in Marketing. Finally, the examples of good practice show that marketing lecturers and students want to have specific tasks for each case. Additionally, lecturers should determine the knowledge and skills that the students would improve as learning outcomes. Relying on the experience and practice of the authors, Table 3 presents an example of teaching notes.

\section{CONCLUSION}

After many years of using cases in lecturing, the authors have identified a lack of lecturer experience in case writing limits the application of cases as a learning method. This paper gives recommendations of using cases in teaching as an interactive method, which supports the development of managerial skills of students, including: presentation skills, working under pressure, team work, problem solving and analytical skills. Based on the results of secondary research and analysis of the instructions provided by the leading global publishing case centers combined with 15 years of the experience of the authors, the steps of case writing were identified. All necessary issues that should be addressed during the process of writing cases, as well as teaching notes were explored. The steps are explained and illustrated with examples of good practice in case writing.

The main limitation of this study is the fact that it only represents the perspective of lecturers. Future research should include the opinion of students as well, which will provide a broader view of applying the case learning method in marketing courses.

This paper should help marketing lecturers to improve their knowledge and skills in writing cases and teaching notes and encourage them to use this method in the classroom in order to provide better learning outcomes.

\section{Literature:}

1. Asia Case Research Centre, Hong Kong University. (2016, October 16). Retrieved from http://www.acrc. hku.hk/casecompetition16/index.asp

2. AT Kearney Slovenia. Connecting social media to mobile banking in mobile banking applications of SRC, Manager of the future 2012

3. Balakrishnan, M.S. (2010). Writing cases: The difference from a case study research methodology and a teaching case study, Retrieved from http://www. emeraldgrouppublishing.com/products/new/pdf/ teaching_cases.pdf,

4. Burke, M.G., Carter, J.D. and Hughey, W.A. (2013). The use of case study competitions to prepare students for the world of work, Industry \& Higher Education, Vol. 27, No.3, pp. 157-162.

5. Chong, S. (2012). Academic quality management in teacher education: a Singapore perspective, Quality Assurance in Education, Vol. 22, No. 1, pp. 53-64 
6. Crespy, C. T., Rosenthal, D.W. and Stearns, J.M. (1999), Change and Growth: Advances in the Use of Cases in Marketing, Marketing Education Review, Vol.9, pp. 1-3

7. Damnjanovic, V. (2011). Hyundai brand, The Case Centre, p. 98 - 104, CASE - Reference no. 510-038-1

8. Damnjanovic, V. (2011). Touché solutions - response to "Y" generation, Emerald Emerging Markets Case Studies, Retrieved from http://www.emeraldinsight. com/doi/abs/10.1108/20450621111114830?src=recsys \&journalCode $=$ eemcs

9. Damnjanovic, V. (2017). Fiat Automobile Serbia's Brand Challenge: Proudly Made In Serbia Think Globally, Act Locally, Belgrade, Case from Belgrade Business International Case Competition in 2013, The Case Centre

10. Damnjanovic, V.(2011). Marketing in Practice: Applying the Case Study ${ }^{m m}$ Method, Belgrade, FON, pp. 88 - 97

11. David F.R, (2003). Strategic management case writing: suggestions after 20 years of experience, $S A M$ Advanced Management Journal, pp. 36-43.

12. Emerald Emerging Markets Case Studies, Retrieved from http://emeraldgrouppublishing.com/products/ case_studies/index.htm

13. Farhoomand A. (2004). Writing Teaching Cases: A Quick Reference Guide, Communications of the Association for Information Systems, Vol.13, pp. 103-107

14. Hall, H. and Witek, L. (2016). Conditions, Contemporary Importance and Prospects of Higher Education Marketing on the Example of Polish Universities, Procedia Economics and Finance, 39, 206211.

15. Hammond, J.S (1976). Learning by the Case Method, Harvard Business Review, pp 1-4.

16. Harvard Business Publishing, Retrieved from https:// cb.hbsp.harvard.edu/cbmp/pages/home

17. Haskins M.E. (1992). Case Writing: Crafting A Vehicle Of Interest And Impact, Chapter 10, Technical Note titled “Case Writing," UVA-G-0364, the University of Virginia Darden Graduate Business School Foundation

18. Hawes, J.M (2004). Teaching Is Not Telling: The Case Method As A Form Of Interactive Learning, Journal for Advancement of Marketing Education - Vol. 5,pp. 47-54.

19. How to write business case study. (2013, April). WDI Publishing, Retrieved from http://wdi-publishing.com/ DocFiles/PDF/cases/preview/WDI-1429140P.pdf

20. IMD Publishing. (2016). Retrieved from http://www. icmrindia.org/

21. INSEAD Publishing. (2016). Retrieved from https:// cases.insead.edu/publishing/

22. Ivey Case Submission Guidelines. (2016). Retrieved from https://www.iveycases.com/media/3052/Case_ Submission_Guidelines.pdf

23. Karns G.L (2005). An Update of Marketing Student Perceptions of Learning Activities: Structure,
Preferences, and Effectiveness, Journal of Marketing Education, Vol. 27,pp. 163

24. Kolb, A.Y. and Kolb, D.A. (2005). Learning styles and learning spaces: Enhancing experiential learning in higher education. Academy of management learning \& education, 4(2), 193-212.

25. Leenders, M.R., Mauffette-Leenders, L.A. and Erskine, J. A. (2001). Writing Cases, (Fourth Edition), Ontario, Canada, Ivey Publishing, Richard Ivey School of Business, The University of Western Ontario.

26. Mijatovic, I. and Jednak, S. (2011). Attitudes toward active participation as predictors of student achievement-exploratory research from Serbia, The New Educational Review, Vol. 24, No.2, pp. 258-270

27. Millar, L. (1999). Writing Case Studies: A Manual, Managing Public Sector Records: A Study Programme, International Records Management Trust, UK

28. Rosenthal, D.W. (2015). How to Write Best-selling Cases. Retrieved from http://www.wacra.org/How\%20 to\%20Write\%20Best-Selling\%20Cases.pdf

29. RSM Case Development Centre, Erasmus University, (2016). Retrieved from https://www.rsm.nl/fileadmin/ Images_NEW/CDC/How_to_Write_a_Good_ Teaching_Case.pdf

30. Salles, J.S., Salles, L. and Rosiele, F. (2015). A brief overview of the teaching case method in Brazil, Procedia - Social and Behavioral Sciences, Volume 174, 3641-3644.

31. Sjoblom, L. (2015). Case Teaching Method, AABC Conference, GIBC; 17-20 May 2015, Retrieved from http://www.aabschools.com/cms/attachments/328/ lief_sjoblom_aabs_conference_2015_emerald_mh_ edits.pdf

32. Sjoblom, L. (2014). How to write a teaching note. Emerald Emerging Markets Case Studies. Retrieved from http://www.emeraldgrouppublishing.com/ products/case_studies/authors.htm

33. Swiercz, P.M. (2016). SWIF Learning: A Guide to Student Written-Instructor Facilitated Case Writing, World Association for Case Method Research \& Application. Retrieved from http://www.wacra.org/ Student\%20Case\%20Writing\%20Guide\%20-\%20 SWIF\%20Manual.pdf

34. The Case Centre (2016). Submission guidelines. Retrieved from http://www.thecasecentre.org/ educators/submitcases/process/how

35. The Case Centre, Cranfield University, UK, https:// www.thecasecentre.org/main/

36. The Times 100 Business Case Studies, Teaching Business Case by example, http://businesscasestudies. co.uk/

37. Yadav, A., Lundeberg, M.A., DeSchryver, M., Dirkin, K.H., Schiller, N., Maier, K. and Herreid, C. F. (2007). Teaching science with case studies: A survey of faculty perceptions on the benefits and challenges of using cases. Journal of College Science Teaching, 37(1), 34-38. 


\section{Apstrakt:}

\section{Kako pisati studije slučaja u edukaciji iz marketinga?}

Ema Nešković, Slavica Cicvarić Kostić, Vesna Damnjanović

Ovaj rad daje uputstva za pisanje studija slučaja i savete za nastavnike za realizaciju časova iz oblasti marketinga u visokom obrazovanju. Studije slučaja se često koriste u učenju koje se zasniva na rešavanju problema, gde se studenti ohrabruju da preuzmu ulogu onoga ko rešava problem. Preporuke za pisanje studije slučaja su zasnovane na analizi primera studija slučaja iz marketinga, objavljenih u najeminentnijim globalnim izdavačkim bazama, kao i na 15 godina iskustva autora u ovoj oblasti. U ovom radu objašnjava se proces pisanja studija slučaja u zavisnosti od izvora podataka, uz davanje odgovora na sva pitanja koja se javljaju tokom procesa. Pisanje uputstava za nastavnike predstavlja pripremu dodatnog materijala koji pomaže da predavač razume razlog za pisanje studije slučaja, pitanja koja mogu da se jave tokom pisanja, kao i profesionalne ili teorijske teme koje je potrebno spomenuti u okviru diskusije. Ovaj rad bi trebalo da doprinese interaktivnom učenju i da obezbedi predavačima detaljne preporuke za pisanje studija slučaja u oblasti marketinga.

Ključne reči: pisanje studija slučaja, uputstva za nastavnike, marketing, visoko obrazovanje

\section{Kontakt:}

Vesna Damnjanović, vanredni profesor damvesna@fon.bg.ac.rs

Slavica Cicvarić Kostić, vanredni profesor cicvarics@fon.bg.ac.rs

Ema Nešković, asistent ema.neskovic@fon.bg.ac.rs

Fakultet organizacionih nauka Univerzitet u Beogradu Jove llića 154, Beograd 